\title{
Uji Validasi Bahan Ajar Berbasis Keunggulan Lokal di SDN Gili Matra, Lombok Utara Nusa Tenggara Barat
}

\author{
Akhmad Sukri $^{1}$, Bq. Muli Harisanti ${ }^{2}$, Bq. Sri Wahyuni ${ }^{3}$, Suharti ${ }^{4}$, Amirudin ${ }^{5}$ \\ 1,2 Jurusan Biologi, FPMIPA, IKIP Mataram \\ 3,4,5 SDN 1 Gili Indah \\ Email: ${ }^{1}$ akhmadsukri@ikipmataram.ac.id
}

\begin{abstract}
Abstrak
Taman Wisata Perairan (TWP) Gili Matra yang terdiri dari Gili Air, Gili Meno dan Gili Trawangan merupakan lokasi wisata populer dan banyak dikenal oleh wisatawan nusantara dan mancanegara. TWP Gili Matra terkenal dengan pesona pantai dan alam bawah laut yang eksotis terutama terumbu karang. Kerusakan terumbu karang di daerah Nusa Tenggara Barat dan TWP Gili Matra telah terjadi selama kurun waktu 10 tahun terakhir. Kerusakan terumbu karang di TWP Gili Matra disebabkan oleh faktor pemutihan karang (coral bleaching), pengeboman ikan, dan pelepasan jangkar. Akibat kerusakan ekosistem terumbu karang di TWP Gili Matra dikhawatirkan berpengaruh terhadap aspek sosial ekonomi masyarakat sekitar. Pelestarian ekosistem terumbu karang melalui pembentukan kesadaran telah dilakukan oleh Sukri (2016) melalui penyusunan bahan ajar berbasis keunggulan lokal di Sekolah Dasar Gili Matra. Upaya ini diharapkan dapat menumbuhkan kesadaran sejak dini kepada peserta didik akan pentingnya keberadaan dan upaya pelestarian ekosistem terumbu karang di Gili Matra. Bahan ajar yang telah disusun tersebut perlu divalidasi untuk memperoleh bahan ajar siap pakai yang memilik kelayakan dari berbagai aspek seperti penggunaan bahasa yang baik dan benar, kebenaran isi atau substansi, dan aspek tampilan dan penyajian. Berdasarkan hasil uji validasi isi atau substansi bahan ajar, diketahui bahwa secara keseluruhan substansi atau isi bahan ajar telah sesuai dan berada pada kategori sangat baik (rerata skor $=3,4$ ), sedangkan dari segi ketepatan penggunaan bahasa, bahan ajar yang telah disusun berada pada kategori sangat baik (rerata skor $=3,5$ ), dan dari segi kelayakan penyajian dan tampilan, bahan ajar berbasis keunggulan lokal yang telah disusun berada pada kategori sangat baik (rerata skor $=3,8$ ). Secara keseluruhan, baik dari aspek isi atau substansi, ketepatan penggunaan bahasa, dan kelayakan penyajian dan tampilan, bahan ajar yang telah disusun berada pada kategori sangat baik dan layak untuk digunakan.
\end{abstract}

Kata kunci: Perangkat Pembelajaran; Keunggulan Lokal; Gili Matra

\section{Validation Test of Local Advantage based Teaching Materials at Gili Matra Elementary School, North Lombok, West Nusa Tenggara}

\begin{abstract}
Gili Matra's Aquatic Park (TWP Gili Matra) consisting of Gili Air, Gili Meno and Gili Trawangan is a popular tourism object and widely known by domestic and foreign tourists. TWP Gili Matra is famous for its exotic seaside and underwater charms, especially coral reefs. Damage to coral reefs in the area of West Nusa Tenggara and TWP Gili Matra has occurred during the last 10 years. Damage to coral reefs in TWP Gili Matra is caused by coral bleaching, fish bombing, and anchorage. As a result of damage to coral reef ecosystems in TWP Gili Matra feared to affect the socio-economic aspects of the surrounding community. Conservation of coral reef ecosystems through the establishment of awareness has been done by Sukri (2016) through the preparation of teaching materials based on local advantage in Gili Matra Elementary School. This effort is expected to raise awareness early on to the learners of the importance of the existence and conservation of coral reef ecosystems in Gili Matra. The instructional materials that have been compiled need to be validated to obtain ready-made teaching materials that have the feasibility of various aspects such as the use of good and correct language, the truth of content or substance, and aspects of appearance and presentation. Based on the validation test of the content or the substance of the teaching materials, it is known that the overall substance or content of the teaching
\end{abstract}


materials has been appropriate and is in very good category (score average $=3.4$ ), while in terms of the accuracy of language use, very good category (average score $=3.5$ ), and in terms of feasibility of presentation and display arranged is in very good category (score average $=3.8$ ). Overall, both in terms of content or substance, the accuracy of language usage, and the feasibility of presentation and display, the instructional materials that have been arranged are in very good category and worthy to be used.

Keywords: Teaching materials; Local Advantage; Gili Matra

\section{PENDAHULUAN}

Taman Wisata Perairan (TWP) Gili Matra yang terdiri dari Gili Air, Gili Meno dan Gili Trawangan merupakan lokasi wisata populer dan banyak dikenal oleh wisatawan nusantara dan mancanegara. TWP Gili Matra terkenal dengan pesona pantai dan alam bawah laut yang eksotis teruma terumbu karang. Seiring dengan berjalannya waktu, jumlah wisatawan lokal maupun asing yang berkunjung ke Gili Matra khususnya Gili Trawangan semakin bertambah (Yulianto et al, 2007). Semakin besar jumlah wisatawan yang berkunjung ke Gili Matra, maka semakin besar beban lingkungan yang ditanggung. Bachtiar dan Gayles (2014) melaporkan bahwa terjadi perkembangan pariwisata yang tidak terkendali di TWP Gili Matra yang mengakibatkan perubahan profil terumbu karang di ketiga gili terutama Gili Trawangan.

Kerusakan terumbu karang di daerah Nusa Tenggara Barat dan TWP Gili Matra telah terjadi selama kurun waktu 10 tahun terakhir (Mukhlis, 2011). Lebih lanjut Bachtiar (2004) memaparkan bahwa kerusakan terumbu karang di TWP Gili Matra disebabkan oleh faktor pemutihan karang (coral bleaching), pengeboman ikan, dan pelepasan jangkar. Akibat kerusakan ekosistem terumbu karang di TWP Gili Matra dikhawatirkan berpengaruh terhadap aspek sosial ekonomi masyarakat sekitar. Pesona alam bawah laut berupa ekosistem terumbu karang merupakan penopang utama wisata bahari di TWP Gili Matra. Keberadaan ekosistem terumbu karang sangat penting baik untuk kepentingan ekowisata juga sebagai sumber pendapatan nelayan sekitar yang berada di TWP Gili Matra karena ekosistem terumbu karang merupakan habitat utama beberapa ikan yang memiliki nilai ekonomis tinggi.

Pelestarian ekosistem terumbu karang di TWP Gili Matra selain dilakukan melalui upaya fisik seperti tranplantasi dan penggunaan teknologi biorock, juga dilakukan melalui upaya nonfisik melalui pembentukan kesadaran masyarakat tentang pentingnya menjaga ekosistem terumbu karang di TWP Gili Matra. Pelestarian ekosistem terumbu karang melalui pembentukan kesadaran telah dilakukan oleh Sukri (2016) melalui penyusunan bahan ajar berbasis keunggulan lokal di Sekolah Dasar Gili Matra. Upaya ini diharapkan dapat menumbuhkan kesadaran sejak dini kepada peserta didik akan pentingnya keberadaan dan upaya pelestarian ekosistem terumbu karang di Gili Matra. Bahan ajar yang telah disusun tersebut perlu divalidasi untuk memperoleh bahan ajar siap pakai yang memilik kelayakan dari berbagai aspek seperti penggunaan bahasa yang baik dan benar, kebenaran isi atau substansi, dan aspek tampilan dan penyajian. Tulisan ini mengulas hasil uji validasi bahan ajar berbasis keunggulan lokal di SDN Gili Matra, Lombok Utara.

\section{METODE PELAKSANAAN}

Kegiatan validasi bahan ajar mengadopsi langkah pengembangan bahan ajar berbasis keunggulan lokal di SDN Gili Matra yang telah dilakukan oleh Sukri (2016) mengikuti langkah-langkah sebagai berikut (1) tahap analisis kebutuhan, (2) tahan desain, dan (3) tahap pengembangan dan implementasi. Tahapan pengembangan perangkat yang telah dilakukan yaitu (1) tahap analisis kebutuhan, dan (2) tahap desain, sedangkan tahap ketiga dari pengembangan ini yaitu pengembangan dan implementasi dilakukan melalui uji validasi, 
yaitu uji validasi isi atau substansi, uji validasi penggunaan bahasa Indonesia, dan uji validasi tampilan atau penyajian bahan ajar. Tulisan ini memaparkan hasil uji validasi bahan ajar berbasis keunggulan lokal di SDN Gili Matra yang telah dikembangkan sebelumnya oleh Sukri (2016).

\section{HASIL DAN PEMBAHASAN}

\section{Hasil Uji Validasi Isi atau Substansi}

Uji validasi isi atau substansi dilakukan oleh ahli ekologi pesisir dan laut. Uji validasi isi dilihat berdasarkan sepuluh komponen penilaian yang memuat seluruh aspek konten atau isi bahan ajar meliputi silabus, rencana pelaksanaan pembelajaran (RPP), dan bahan ajar komik. Hasil uji validasi isi ditampilkan pada Tabel 1 berikut.

Tabel 1. Hasil Uji Validasi Isi Bahan Ajar Berbasis Keunggulan Lokal

\begin{tabular}{|c|c|c|c|c|}
\hline No & Komponen Penilaian & $\begin{array}{c}\text { Skor } \\
\text { Penilaian }\end{array}$ & $\begin{array}{c}\text { Kualifikasi } \\
\text { Penilaian }\end{array}$ & $\begin{array}{l}\text { Masukan } \\
\text { Perbaikan }\end{array}$ \\
\hline 1 & $\begin{array}{l}\text { Kesesuaian Standar Kompetensi, Kompetensi } \\
\text { Dasar dengan Materi Pokok }\end{array}$ & 3 & & \\
\hline 2 & Ketepatan indikator dengan materi pokok & 4 & & \\
\hline 3 & $\begin{array}{l}\text { Materi pokok menggambarkan materi terumbu } \\
\text { karang secara komprehensif }\end{array}$ & 3 & & \\
\hline 4 & $\begin{array}{l}\text { Skenario pembelajaran sesuai dengan } \mathrm{SK}, \mathrm{KD} \text {, dan } \\
\text { materi pokok }\end{array}$ & 3 & & \\
\hline 5 & $\begin{array}{l}\text { Substansi materi sesuai dengan kebenaran } \\
\text { keilmuan }\end{array}$ & 3 & & \\
\hline 6 & $\begin{array}{l}\text { Uraian materi terumbu karang sesuai dengan } \\
\text { tingkatan kognitif peserta didik }\end{array}$ & 4 & & \\
\hline 7 & $\begin{array}{l}\text { Ilustrasi yang disajikan sesuai dengan materi } \\
\text { terumbu karang }\end{array}$ & 4 & & \\
\hline 8 & Tahapan penyajian materi terumbu karang runtut & 4 & & \\
\hline 9 & $\begin{array}{l}\text { Sajian materi terumbu karang sesuai dengan SK, } \\
\mathrm{KD} \text {, materi pokok, dan indikator }\end{array}$ & 3 & & \\
\hline 10 & $\begin{array}{l}\text { Cerita dalam komik sesuai dengan materi terumbu } \\
\text { karang }\end{array}$ & 3 & & \\
\hline \multicolumn{2}{|c|}{ Rerata Keseluruhan } & 3,4 & Sangat baik & \\
\hline \multicolumn{5}{|c|}{$\begin{array}{l}\text { Keterangan: } \\
* \quad \text { Skor penilaian pada interval 1-4 (1= kurang baik, } 2=\text { cukup baik, } 3=\text { baik, dan } 4=\text { sangat baik }) \\
\text { ** } \text { Kualifikasi penilaian }\end{array}$} \\
\hline
\end{tabular}

Rerata hasil uji validasi isi atau substansi menunjukkan bahwa dari segi substansi, bahan ajar berbasis keunggulan lokal yang telah disusun berada pada kategori sangat baik. Namun berdasarkan masukan validator, ada beberapa catatan yang perlu dipertimbangkan untuk diperbaiki atau direvisi, yaitu (1) dalam perumusan indikator sebaiknya menggunakan kata kerja operasional, sehingga mudah diukur. Misalnya 'memahami perbedaan antara karang dan terumbu karang' diganti menjadi 'menjelaskan perbedaan antara karang dan terumbu karang', (2) dalam menyusun tujuan pembelajaran hendaknya memperhatikan asas $\mathrm{ABCD}$, yaitu $\mathrm{A}=$ audience, $\mathrm{B}=$ behavior, $\mathrm{C}=$ conditions, dan $\mathrm{D}=$ degree . Sebagai contoh misalnya tujuan pembelajaran 'siswa memahami perbedaan antara karang dan terumbu karang' sebaiknya diganti menjadi 'melalui bacaan komik Kaka dan Kiki si petualang (C) peserta didik (A) dapat menjelaskan empat perbedaan (D) terumbu karang dan karang', (3) penjelasan tujuan pembelajaran oleh guru sebaiknya dimasukkan kedalam kegiatan apersepsi bukan pada bagian kegiatan inti, (4) model 
penilaian disesuaikan dengan materi pokok yang diajarkan.

Berdasarkan saran dan masukan dari validator, maka beberapa revisi telah dilakukan, yaitu (1) merubah beberapa indikator yang telah disusun menggunakan kata kerja operasional, sehingga mudah diukur, (2) mengganti rumusan tujuan pembelajaran sesuai dengan asas $\mathrm{ABCD}$ (Audience, Behavior, Conditions, dan Degree), (3) revisi pada skenario pembelajaran dengan memasukkan penyampaian tujuan pembelajaran pada kegiatan apersepsi, dan (4) merubah beberapa aspek penilaian yang disesuaikan dengan materi pokok yang diajarkan.

\section{Hasil Uji Validasi Ketepatan Penggunaan Bahasa}

Uji validasi ketepatan penggunaan bahasa dilakukan oleh ahli bahasa Indonesia. Uji validasi ketepatan penggunaan bahasa Indonesia dinilai berdasarkan sepuluh komponen penilaian. Hasil uji validasi ketepatan penggunaan bahasa ditampilkan pada Tabel 2 berikut.

Tabel 2. Hasil Uji Validasi Ketepatan Penggunaan Bahasa Bahan Ajar Berbasis Keunggulan Lokal

\begin{tabular}{|c|c|c|c|c|}
\hline No & Komponen Penilaian & $\begin{array}{l}\text { Skor } \\
\text { Penilaian }\end{array}$ & $\begin{array}{l}\text { Kualifikasi } \\
\text { Penilaian }\end{array}$ & $\begin{array}{l}\text { Masukan } \\
\text { Perbaikan }\end{array}$ \\
\hline 1 & $\begin{array}{l}\text { Bahasa yang digunakan sederhana sesuai dengan } \\
\text { perkembangan kognitif perserta didik }\end{array}$ & 4 & & \\
\hline 2 & $\begin{array}{l}\text { Materi terumbu karang disampaikan secara lugas } \\
\text { dan jelas sesuai karakter peserta didik }\end{array}$ & 4 & & \\
\hline 3 & $\begin{array}{l}\text { Penulisan bahan ajar sesuai dengan kaedah bahasa } \\
\text { baku }\end{array}$ & 3 & & \\
\hline 4 & $\begin{array}{l}\text { Penggunaan dan penulisan istilah-istilah sudah } \\
\text { tepat }\end{array}$ & 3 & & \\
\hline 5 & $\begin{array}{l}\text { Struktur kalimat sudah disusun dengan baik dan } \\
\text { benar }\end{array}$ & 3 & & \\
\hline 6 & $\begin{array}{l}\text { Keterkaitan informasi antara kalimat satu dengan } \\
\text { yang lainnya sudah baik }\end{array}$ & 4 & & \\
\hline 7 & Ketepatan ukuran dan jenis huruf & 4 & & \\
\hline 8 & Ketepatan jarak dan spasi & 4 & & \\
\hline 9 & Ketepatan penggunaan tanda baca & 3 & & \\
\hline 10 & Ketepatan penggunaan ilustrasi/gambar & 3 & & \\
\hline \multicolumn{2}{|c|}{ Rerata Keseluruhan } & 3,5 & Sangat baik & \\
\hline \multicolumn{5}{|c|}{$\begin{array}{l}\text { Keterangan: } \\
* \quad \text { Skor penilaian pada interval } 1-4 \text { (1= kurang baik, } 2=\text { cukup baik, } 3=\text { baik, dan } 4=\text { sangat baik) } \\
* * \quad \text { Kualifikasi penilaian } \\
3<S \leq 4 \text { (Sangat baik), } 2<S \leq 3 \text { (Baik), } 1<S \leq 2 \text { (Cukup baik), } S \leq 1 \text { (Kurang baik), } S=\text { skor }\end{array}$} \\
\hline
\end{tabular}

Berdasarkan hasil uji validasi ketepatan penggunaan bahasa (Tabel 1), diketahui bahwa secara keseluruhan penggunaan bahasa Indonesia bahan ajar berbasis keunggulan lokal di SDN Gili Matra berada pada kategori sangat baik $(\mathrm{s}=3,5)$. Namun ada beberapa masukan dari validator terkait penggunaan bahasa Indonesia, yaitu (1) istilah-istilah yang dimunculkan terkait dengan materi terumbu karang perlu diuraikan dengan lebih sederhana, bisa menggunakan pengandaian-pengandaian yang sudah dikenal oleh siswa, sehingga nantinya muatan konten materi yang disiapkan lewat cerita dapat dipahami oleh siswa, (2) dialog-dialog antar tokoh ada baiknya disesuaikan dengan daya jangkau pemahaman tingkat siswa SD. Terkait dengan masukan-masukan dari validator ini, kemudian dilakukan revisi seperti penggunaan tokoh-tokoh yang sesuai dengan tema cerita terumbu karang yaitu "Kaka dan 
Kiki si Petualang” yang bercerita tentang petualangan Kaka dan Kiki si anak kecil yang melihat kerusakan terumbu karang di Gili Matra akibat berbagai aktivitas manusia dan gejala alam yang harus segera ditangani. Terkait masukan validator tentang dialogdialog yang disesuaikan dengan tingkat pemahaman anak SD hal ini sudah diadopsi dan direvisi pada berbagai dialog Kaka dan Kiki dengan kepala sekolah, masyarakat dan teman-teman mainnya, sehingga lebih dapat dipahami oleh peserta didik di SDN Gili Matra.

\section{Hasil Uji Validasi Kelayakan Penyajian dan Tampilan Bahan Ajar}

Uji validasi kelayakan penyajian dan tampilan bahan ajar dilakukan oleh ahli teknologi pembelajaran. Uji validasi kelayakan penyajian dan tampilan mencakup komponen Standar Kompetensi (SK), Kompetensi Dasar (KD), Silabus, Rencana Pelaksanaan Pembelajaran (RPP), dan bahan ajar komik. Hasil uji validasi kelayakan penyajian dan tampilan ditampilkan pada Tabel 3 berikut.

Tabel 3. Hasil Uji Validasi kelayakan penyajian dan tampilan Bahan Ajar Berbasis Keunggulan Lokal

\begin{tabular}{|c|c|c|c|c|}
\hline No & Komponen Penilaian & $\begin{array}{l}\text { Skor } \\
\text { Penilaian }\end{array}$ & $\begin{array}{l}\text { Kualifikasi } \\
\text { Penilaian }\end{array}$ & $\begin{array}{l}\text { Masukan } \\
\text { Perbaikan }\end{array}$ \\
\hline $\mathbf{A}$ & \multicolumn{4}{|l|}{ Rumusan SK, KD, Silabus } \\
\hline 1 & Alasan rasional penyusunan SK dan KD & 4 & & \\
\hline 2 & Kejelasan indikator & 4 & & \\
\hline 3 & Batasan ruang lingkup SK dan KD & 4 & & \\
\hline 4 & Kejelasan rumusan standar kompetensi & 3 & & \\
\hline 5 & Kejelasan dan ketercukupan kompetensi dasar & 4 & & \\
\hline 6 & Kecukupan materi pokok dalam silabus & 3 & & \\
\hline 7 & $\begin{array}{l}\text { Kegiatan pembelajaran sesuai dengan SK, KD, } \\
\text { indikator, dan materi pokok }\end{array}$ & 4 & & \\
\hline 8 & Penentuan sumber belajar dalam silabus & 4 & & \\
\hline 9 & Penentuan evaluasi pembelajaran dalam silabus & 4 & & \\
\hline 10 & Ketepatan alokasi waktu dalam silabus & 4 & & \\
\hline B & Bahan Ajar Komik & & & \\
\hline 11 & Kejelasan judul & 3 & & \\
\hline 12 & Urutan sajian & 4 & & \\
\hline 13 & $\begin{array}{l}\text { Konsistensi KD dan indikator dalam silabus } \\
\text { dengan uraian materi dalam bahan ajar }\end{array}$ & 4 & & \\
\hline 14 & $\begin{array}{l}\text { Kesesuaian materi terumbu karang dengan KD dan } \\
\text { indikator }\end{array}$ & 4 & & \\
\hline 15 & Kejelasan uraian materi terumbu karang & 4 & & \\
\hline 16 & Kejelasan ilustrasi/gambar/ contoh & 4 & & \\
\hline \multicolumn{2}{|c|}{ Rerata Keseluruhan } & 3,8 & Sangat baik & \\
\hline \multicolumn{5}{|c|}{$\begin{array}{l}\text { Keterangan: } \\
* \quad \text { Skor penilaian pada interval 1-4 ( } 1=\text { kurang baik, } 2=\text { cukup baik, } 3=\text { baik, dan } 4=\text { sangat baik) } \\
* * \quad \text { Kualifikasi penilaian } \\
3<S \leq 4 \text { (Sangat baik), } 2<S \leq 3 \text { (Baik), } 1<S \leq 2 \text { (Cukup baik), } S \leq 1 \text { (Kurang baik), } S=\text { skor }\end{array}$} \\
\hline
\end{tabular}

Berdasarkan hasil uji validasi kelayakan penyajian dan tampilan bahan ajar, diketahui bahwa masing-masing item komponen penilaian berada pada kategori baik (skor 3) dan sangat baik (skor 4).
Secara keseluruhan, hasil uji validasi kelayakan penyajian dan tampilan bahan ajar berada pada kategori sangat baik $(\mathrm{s}=$ 3,8). Namun ada beberapa saran masukan dari validator, yaitu (1) posisi judul 
sebaiknya ditempatkan pada posisi bagian atas cover bahan ajar, dan (2) gradasi warna cover perlu ditambahkan agar lebih menarik. Berdasarkan masukan validator, maka dilakukan revisi atas kedua masukan tersebut.

\section{KESIMPULAN}

Berdasarkan hasil uji validasi isi atau substansi bahan ajar, diketahui bahwa secara keseluruhan substansi atau isi bahan ajar telah sesuai dan berada pada kategori sangat baik (rerata skor $=3,4$ ), sedangkan dari segi ketepatan penggunaan bahasa, bahan ajar yang telah disusun berada pada kategori sangat baik (rerata skor $=3,5$ ), dan dari segi kelayakan penyajian dan tampilan, bahan ajar berbasis keunggulan lokal yang telah disusun berada pada kategori sangat baik (rerata skor $=3,8$ ). Secara keseluruhan, baik dari aspek isi atau substansi, ketepatan penggunaan bahasa, dan kelayakan penyajian dan tampilan, bahan ajar yang telah disusun berada pada kategori sangat baik dan layak untuk digunakan.

\section{DAFTAR PUSTAKA}

Bachtiar, I. (2004). Status terumbu karang di Propinsi Nusa Tenggara Barat: sebuah kajian. Jurnal Biologi Tropis, Vol 5(1): 1-9.

Bachtiar, I. and Gayles, M. (2014). Tourist satisfaction in the Marine Recreation Park of Gili Matra.
Kabupaten Lombok Barat. Proceeding of International Research Symposium on Sustainable Tourism Development. Mataram, 29-30 ${ }^{\text {th }}$ August 2014. Pp 56-65.

Hannafin, M.J dan Peck, K.L. (1988). The Design, Development, and Evaluation of Instructional Software. New York: Mc Millan Publishing Company.

Mukhlis. (2011). Ekosistem Terumbu Karang di Kawasan Wisata Bahari Gili Trawangan Lombok dan Pengaruh Hidrokarbon pada Masa Lethal Karang Acropora spp. Disertasi tidak diterbitkan. Malang: Universitas Negeri Malang.

Sukri, A., Harisanti, Bq Muli.,Wahyuni, Bq Sri.,Suharti.,\& Amiruddin. (2016). Penyusunan Perangkat Pembelajaran Berbasis Keunggulan Lokal Daerah di SDN 1 Gili Indah, Lombok Utara, Prosiding $2^{\text {nd }}$ Symbion (Symposium on Biology Education) Edubioconservation for Sustainable Living, Yogyakarta: 27 Agustus.

Yulianto, G.,Fahrudin, A. \& Kusmaningsih, N. (2007). Analisis permintaan rekreasi dan strategi pengembangan wisata bahari di Gili Trawangan Kabupaten Lombok Barat, Provinsi Nusa Tenggara Barat. Buletin Ekonomi Perikanan, Vol 6(2): 7298. 